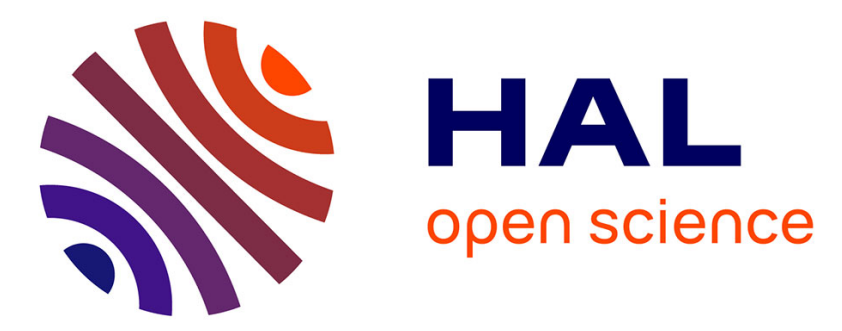

\title{
Modeling of cobalt and copper speciation in metalliferous soils from Katanga (Democratic Republic of Congo)
}

Olivier Pourret, Bastien Lange, David Houben, Gilles Colinet, Mylor Shutcha, Michel-Pierre Faucon

\section{To cite this version:}

Olivier Pourret, Bastien Lange, David Houben, Gilles Colinet, Mylor Shutcha, et al.. Modeling of cobalt and copper speciation in metalliferous soils from Katanga (Democratic Republic of Congo). Journal of Geochemical Exploration, 2015, 149, pp.87-96. 10.1016/j.gexplo.2014.11.011 . hal02136344

\section{HAL Id: hal-02136344 \\ https://hal.science/hal-02136344}

Submitted on 22 May 2019

HAL is a multi-disciplinary open access archive for the deposit and dissemination of scientific research documents, whether they are published or not. The documents may come from teaching and research institutions in France or abroad, or from public or private research centers.
L'archive ouverte pluridisciplinaire HAL, est destinée au dépôt et à la diffusion de documents scientifiques de niveau recherche, publiés ou non, émanant des établissements d'enseignement et de recherche français ou étrangers, des laboratoires publics ou privés. 


\section{Accepted Manuscript}

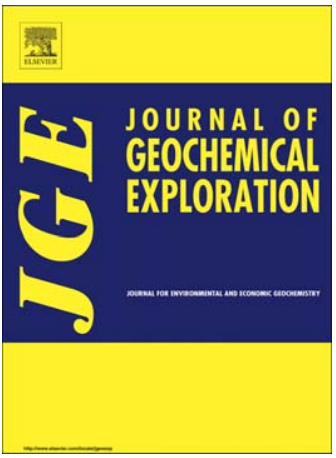

PII:

DOI:

S0375-6742(14)00380-X

Reference:

doi: 10.1016/j.gexplo.2014.11.011

GEXPLO 5486

To appear in: $\quad$ Journal of Geochemical Exploration

Received date: $\quad 15$ April 2014

Accepted date: $\quad 24$ November 2014

Please cite this article as: Pourret, Olivier, Lange, Bastien, Houben, David, Colinet, Gilles, Shutcha, Mylor, Faucon, Michel-Pierre, Modeling of cobalt and copper speciation in metalliferous soils from Katanga (Democratic Republic of Congo), Journal of Geochemical Exploration (2014), doi: 10.1016/j.gexplo.2014.11.011

This is a PDF file of an unedited manuscript that has been accepted for publication. As a service to our customers we are providing this early version of the manuscript. The manuscript will undergo copyediting, typesetting, and review of the resulting proof before it is published in its final form. Please note that during the production process errors may be discovered which could affect the content, and all legal disclaimers that apply to the journal pertain. 


\section{Modeling of cobalt and copper speciation in metalliferous soils from Katanga (Democratic Republic of Congo)}

Olivier Pourret $^{1 *}$, Bastien Lange ${ }^{1,2}$, David Houben ${ }^{1}$, Gilles Colinet ${ }^{3}$, Mylor Shutcha ${ }^{4}$, Michel-Pierre Faucon ${ }^{1}$

${ }^{1}$ HydrISE, LaSalle Beauvais, 60026 Beauvais cedex, France

${ }^{2}$ Laboratoire d'Ecologie Végétale et Biogéochimie, Université Libre Bruxelles, 1050 Bruxelles, Belgium

${ }^{3}$ Unité Science du Sol, Gembloux Agro Bio-Tech, Université de Liège, 5030 Gembloux, Belgium

${ }^{4}$ Faculté des Sciences Agronomiques, Université de Lubumbashi, Lubumbashi, Democratic Republic of Congo

*Corresponding author: Tel.: +33344068979; Fax: + 33344068970. E-mail address: olivier.pourret@lasalle-beauvais.fr. 


\section{Abstract}

Cobalt and copper fractionation in soils from Copperbelt of Upper Katanga (Democratic Republic of Congo) was investigated to understand their mobility. Indeed, fractionation and mobility of $\mathrm{Co}, \mathrm{Cu}$ and $\mathrm{Zn}$ was assessed using the application of both ammonium acetate-EDTA extraction and speciation modeling (WHAM 6) to organic-rich soils contaminated by these metals. The resulting data set covers wide ranges of conditions $(\mathrm{pH}$, trace metals concentration, natural and anthropogenic soils) enabling comparisons between extraction and speciation modeling. Good agreement between the observations and model predictions (especially for $\mathrm{Co}$ and $\mathrm{Cu}$ ) supports the validity of both approaches. A positive correlation was found between organic-bound and inorganic Co concentrations obtained by speciation modeling and extractable Co concentrations. Speciation calculation results were further considered to evaluate more precisely metal speciation and gain insights into the variability between sites considering or not major competitors (i.e., $\mathrm{Ca}$ and $\mathrm{Mg}$ ). When the model was adjusted to remove major competitors binding and their competition with other metals, the predicted binding with $\mathrm{HM}$ of the studied metals (i.e., $\mathrm{Co}, \mathrm{Cu}$ and $\mathrm{Zn}$ ) increased. The extent of major cation competition is thus of potential significance. Thus to model the system as close as possible to natural and field conditions, major cation competition with metals should be selected. Strong affinity of Mn-oxides for Co, may explain lower Co mobility of Mn-rich soils. The high $\mathrm{Mn}$ and Fe contents of $\mathrm{Cu}-\mathrm{Co}$ soils from Katanga may actually exert a protective effect against the toxic effects of Co. Finally Cu-Co speciation modeling of contaminated sites may lead to better understanding metal fractionation and guide to define different practices of phytoremediation.

Keywords: cobalt, manganese oxide, humic substances, copper 


\section{Introduction}

Knowledge of soil geochemistry is fundamental to determine the effects stemming from an anthropogenic activity, and its impact on the geo-ecosystems as a result of its toxicities (Albanese et al., 2007; Cicchella et al., 2005; Giaccio et al., 2012; Guillén et al., 2011, 2012). Metal partitioning exerts a major control on the transport and retention of trace metals in soils (e.g., Kabata-Pendias and Pendias, 2001). For many soil biota, the availability of soil trace metals depends upon concentrations and chemical forms in the soil (Kabata-Pendias and Mukherjee, 2007; Reeder et al., 2006; Smith and Huyck, 1999). In particular, free metal ion concentrations (e.g., $\mathrm{Co}^{2+}, \mathrm{Cu}^{2+}$ and $\mathrm{Zn}^{2+}$ ) provide the best guide to both partitioning and availability (Dean, 2007).

To assess metal mobility and associated availability, quantitative and predictive descriptions of metal partitioning in soils are needed. Two approaches can be identified. First, empirical relationships have been derived, by multiple regression analysis by relating concentrations of either total dissolved metal or free metal ions to key soil variables such as total soil metal, $\mathrm{pH}$, soil organic matter (SOM) content and Mn and Fe oxyhydroxides (Dean, 2007). This approach has provided a good description of metal chemistry, principally in metal-contaminated soils with relatively low levels of organic matter (Abedin et al., 2012). However, they do not appear to have been applications to more organic-rich soils (organic carbon content $>10 \%$ ) (Tipping et al., 2003). A second approach is to use speciation models that describe the interactions taking into account competitive binding to soil materials, including SOM. In the last decades, several authors (Benedetti et al., 1996; Tipping, 2002) were able to describe metal binding to organic matter in organic-rich horizons of various soils as well as to account for partitioning of several trace metal elements (e.g., $\mathrm{Cu}$ and $\mathrm{Cd}$ ). 
For the most organic-rich soils, the trace metal partitioning could be reasonably well accounted for, but the involvement of mineral sorbents (e.g., $\mathrm{Mn}$ and $\mathrm{Fe}$ oxyhydroxides) appeared necessary in certain cases to explain the results with more mineral soils.

In the present study, the speciation of $\mathrm{Cu}$ and $\mathrm{Co}$ in soil is characterized by speciation modeling to highlight the $\mathrm{Cu}-\mathrm{Co}$ mobility in organic rich tropical soils of the Copperbelt of Upper Katanga (Democratic Republic of Congo). The resulting data set covers wide ranges of conditions, enabling comparison between extraction and speciation modeling using WHAM 6 (Lofts and Tipping, 1998; Tipping, 1994; Tipping, 1998). Speciation modeling was performed considering or not major competitors (i.e., $\mathrm{Ca}$ and $\mathrm{Mg}$ ) and testing organic matter content (i.e., fraction of humic acid). Such a method will help to identify the factors responsible for metal partitioning, and attempt to predict metal availability. The higher the exchangeable metal concentration, the higher the mobility and the associated risk of transfer will be.

\section{Materials and methods}

\subsection{Study area}

The Copperbelt of Upper Katanga (Democratic Republic of Congo) was selected for the present study as it acts as a major producer of copper and cobalt accounting $5 \%$ and $47.5 \%$ of the world production in 2013, respectively (USGS, 2014). Emissions of $\mathrm{SO}_{2}$ (which causes acid deposition) and metalliferous particles produced from the Cu-smelting industry for over 80 years in the vicinity of Lubumbashi (Democratic Republic of Congo) have degraded woodland and caused its 
replacement by open grassland and bare soil in the area situated downwind of the copper smelter. Metals are then accumulated mainly in the surface horizons of soils in the surrounding area (Narendrula et al., 2012). These soils have accumulated trace metals (i.e., $\mathrm{Co}, \mathrm{Cu}$ and $\mathrm{Zn}$ ) due to the deposition of atmospheric fall-out from oresmelter, the weathering of soil metal-bearing mineral or the presence of mine deposits. Earlier studies showed that metalliferous soils from the study area have higher total concentrations of $\mathrm{Ca}, \mathrm{Mg}, \mathrm{P}, \mathrm{Mn}, \mathrm{Zn}, \mathrm{Cu}$, and $\mathrm{Co}$ compared to nonmetalliferous soils (Faucon et al., 2009; Narendrula et al., 2012). However, $\mathrm{Cu}$ and Co concentrations in soils were very variable among sites. Environmental monitoring and land reclamation initiatives are lacking and environmental contamination study by metals are scarce or not available (Banza et al., 2009; Cheyns et al., 2014; Narendrula et al., 2012; 2013). To assess human exposure to pollution in Katanga, which is a real concern to human health due to the high population density in the contaminated area, Banza et al. (2009) measured metal concentrations in urine of people living close to mines or smelting plants. Concentrations of Co and other metals were higher in people living close to mines or smelting plants (including the site contaminated by the $\mathrm{Cu}$-smelter industry of Lubumbashi), exceeding the baseline value of the Centers for Disease Control and Prevention (Shutcha et al., 2010).

\subsection{Soil sampling and chemical analysis}

Fifteen organic-rich soils contaminated by trace metals were collected from four different metalliferous sites in the region of Lubumbashi (Democratic Republic of Congo) (Table 1). For each sample, a composite bulk surface soil sample (organic layer; $0-10 \mathrm{~cm})$ was collected in each site by mixing three to four subsamples $(100$ - 
$500 \mathrm{~g}$ ) taken according a random design (Faucon et al., 2009). The sites of Etoile and Niamumenda consist of disturbed soils by mining on natural copper hill. The soils from Vallée Karavia are contaminated by atmospheric fallouts from the copper smelter of Lubumbashi containing typically moist soils. Ruashi site consists of mine debris. See Faucon et al. (2009) for more details.

Soil samples were dried at room temperature and sieved $(2 \mathrm{~mm})$. The $\mathrm{pH}$ (water) was determined on a saturated soil-water paste and SOM content was evaluated by loss on ignition $\left(550^{\circ} \mathrm{C}\right.$ for $\left.12 \mathrm{~h}\right)$. The concentrations of available metals were determined using an acetate-EDTA $1 \mathrm{~mol} / \mathrm{L}(\mathrm{pH} 4.65)$ extraction with stirring for $30 \mathrm{~min}(1 / 10 \mathrm{w} / \mathrm{v})$ (Faucon et al., 2011; Faucon et al., 2009). For the determination of total contents of $\mathrm{Co}, \mathrm{Cu}, \mathrm{Fe}, \mathrm{Mn}, \mathrm{Mg}$ and $\mathrm{Ca}$, soils were digested in concentrated $\mathrm{HF}$ and $\mathrm{HClO}_{4}$. After desiccation, the residue was dissolved in $10 \%(\mathrm{v} / \mathrm{v}) \mathrm{HCl}$ and further diluted with deionized water. When needed, a pre-treatment stage of SOM mineralization with concentrated $\mathrm{HNO}_{3}$ was applied (AFNOR, 2001). Supernatant was filtered $(0.45 \mu \mathrm{m}$ cellulose acetate Whatman filters $)$ and analyzed. Element concentrations $(\mathrm{Ca}, \mathrm{Mg}, \mathrm{K}, \mathrm{Cu}, \mathrm{Co}, \mathrm{Mn}, \mathrm{Fe}$ ) were determined by Inductively Coupled Plasma-Optical Emission Spectrometry (Varian Vista MPX) in the Laboratoire d'Ecologie Végétale et Biogéochimie (Univ. Libre Bruxelles, Belgium) (Faucon et al., 2011; Faucon et al., 2009). The precision and accuracy of analysis for element concentrations were determined using BCR-100 for plants as well as in house standards for soils. Analyses agreed with certified values to within $\pm 5 \%$.

\subsection{Chemical speciation calculations}


The main chemical speciation model used in the present work is WHAM 6 (version 6.0.10) which has the same structure as WHAM (Tipping, 1994), including sub-models: (i) Model VI (Tipping, 1998) and (ii) SCAMP (Lofts and Tipping, 1998). Briefly, Model VI consists of a discrete-site description of the cation-complexing properties of fulvic acid (FA) and humic acid (HA), combined with a sub-model for electrostatic effects on specific binding and a Donnan sub-model for counterion accumulation. Metals and protons bind at common sites, some of which are multidentate with respect to the metals. The concentrations of humic material (HM) were derived from the experimental SOM measurements: $50 \%$ of the SOM measured in the field samples were assumed to be HM, themselves being defined as $100 \% \mathrm{HA}$.

The SCAMP model (Lofts and Tipping, 1998) was also used to consider Co, $\mathrm{Cu}$ and $\mathrm{Zn}$ species, as well as $\mathrm{Fe}, \mathrm{Mn}$ and $\mathrm{Al}$ oxides. Briefly, SCAMP describes the equilibrium adsorption of metals by natural particulate and colloidal matter using a combination of sub-models for individual binding phases. Interactions with natural SOM are described with Model VI, and adsorption by oxides with a surface complexation model that allows for site heterogeneity. SCAMP uses published parameters for Model VI, and the parameters for the oxide model are derived from experimental data for metal binding by oxides of $\mathrm{Al}, \mathrm{Si}, \mathrm{Mn}$, and $\mathrm{Fe}$ (III) (Lofts and Tipping, 1998). The data allowed the consideration of three binding phases, namely iron oxide, manganese oxide and organic carbon. Iron oxide and manganese oxide were determined by X ray diffraction (XRD; Bruker XD8 Advance) and identified as goethite and pyrolusite, respectively. Aluminum oxide and carbonate were not considered as they were not identified by XRD analysis; the other mineral phases were clinochlore, muscovite, rutile, and quartz. Heterogenite $(\mathrm{CoOOH})$ was observed in two samples but was not further considered, even if it has been identified as a 
major Co mineral in Katanga (Decrée et al., 2010). Indeed, WHAM 6 does not consider saturation index and mineral precipitation. Besides the three binding phases considered (i.e., iron oxide, manganese oxide and organic carbon) and associated metal fractions, the remaining fraction consists of inorganic metal species (free species and complexes with hydroxides, sulfates...) and was thereafter referred as cationic form, for simplification.

Moreover, it is possible that WHAM 6 overestimates the competition between major cations (i.e., $\mathrm{Ca}$ and $\mathrm{Mg}$ ) and trace metals for binding sites on HM (Hering and Morel, 1996; Kinniburgh et al., 1996; Lofts and Tipping, 1998). The most likely explanation for this is that $\mathrm{Ca}$ and $\mathrm{Mg}$ do not bind as strongly as expected to the strongest binding sites, which dominate trace metal binding. Recent modeling studies have supported this possibility (Pourret et al., 2007a; Tipping, 1998). To assess whether overestimation of competition could significantly affect predictions, some additional modeling was performed by considering $\mathrm{Ca}$ and $\mathrm{Mg}$ which were prevented from binding to $\mathrm{HM}$. It must be emphasized the fact that $\mathrm{Ca}$ and $\mathrm{Mg}$ do not bind to HM was not imply; the objective is to compare predictions made by assuming both the presence and the absence of major cation competition.

WHAM 6 was used to calculate $\mathrm{Co}, \mathrm{Cu}$ and $\mathrm{Zn}$ speciation, using the default parameters (Lofts and Tipping, 1998; Tipping, 1998; Tipping, 2002). All calculations were carried out based on the total metal content and soil solution $\mathrm{pH}$ as previously performed by Ponizovsky et al. (2006). Measurements used for modeling are given in Table 2.

\subsection{Statistical analysis}


Relations between chemical extraction and speciation modeling results were characterized with Pearson correlations (using OriginPro 8.5.0). Linear regression modeling using log-transformed data have been used to represent correlations between $\mathrm{Cu}$, $\mathrm{Co}$ and $\mathrm{Zn}$ fractions in soils and $\mathrm{Cu}$, $\mathrm{Co}$ and $\mathrm{Zn}$ species obtained by modeling (using WHAM 6). Statistically significant differences of metal fractions in soils between modeling hypothesis were determined using a paired-sample Wilcoxon signed rank test. Mean $\mathrm{Cu}-\mathrm{Co}$ fractions (\%) and concentrations among sites were compared by Kruskal-Wallis test. Significance was defined and represented as follow: $* *: \mathrm{p}<0.01, *: \mathrm{p}<0.05, \mathrm{NS}=$ non-significant. 


\section{Results}

The sites Etoile and Niamumenda contain disturbed soils from copper hills. Etoile soils show large concentration of $\mathrm{Mn}$ and Fe oxides as well as a very important Co and $\mathrm{Cu}$ concentrations (from 1,410 mg/kg to $9,463 \mathrm{mg} / \mathrm{kg}$, and from $10,758 \mathrm{mg} / \mathrm{kg}$ to $29,793 \mathrm{mg} / \mathrm{kg}$, for $\mathrm{Co}$ and $\mathrm{Cu}$, respectively; Table 2). Niamumenda soils show lower Co concentrations but still high $\mathrm{Cu}$ concentrations $(132 \mathrm{mg} / \mathrm{kg}$ to $214 \mathrm{mg} / \mathrm{kg}$, and $3,124 \mathrm{mg} / \mathrm{kg}$ to $49,760 \mathrm{mg} / \mathrm{kg}$, for Co and $\mathrm{Cu}$, respectively; Table 2). The other sites Vallée Karavia and Ruashi have been contaminated by atmospheric fallouts from the copper smelter of Lubumbashi and show low Co concentrations (from $31 \mathrm{mg} / \mathrm{kg}$ to $131 \mathrm{mg} / \mathrm{kg}$, and from $145 \mathrm{mg} / \mathrm{kg}$ to $335 \mathrm{mg} / \mathrm{kg}$, respectively for Vallée Karavia and Ruashi; Table 2) and high $\mathrm{Cu}$ contents (from $576 \mathrm{mg} / \mathrm{kg}$ to $8,957 \mathrm{mg} / \mathrm{kg}$, and from $1,147 \mathrm{mg} / \mathrm{kg}$ to 2,657 mg/kg, respectively for Vallée Karavia and Ruashi; Table 2). All four sites display relatively low Zn concentrations (from $75 \mathrm{mg} / \mathrm{kg}$ to $622 \mathrm{mg} / \mathrm{kg}$; Table 2).

Scatter plots of $\log (\mathrm{Co}, \mathrm{Cu}, \mathrm{Zn})$ extractable versus $\log (\mathrm{Co}, \mathrm{Cu}, \mathrm{Zn})$ total concentrations are given in Fig. 1. Log extractable metal concentrations are positively correlated to log total metal concentrations in soils. Correlations are highly significant for $\mathrm{Co}$ and $\mathrm{Cu}(\mathrm{r}=0.92$ and 0.86 , respectively, $\mathrm{p}<0.001)$, whereas the correlation is significant but slightly lower for $\mathrm{Zn}(\mathrm{r}=0.32, \mathrm{p}<0.01)$. The estimation of metal availability using the AA-EDTA extraction method is known to be more suitable for high metal concentrations (Peters, 1999), which is the case for Co and $\mathrm{Cu}$ but not for Zn (Table 2). As recently shown by Collins and Kinsela (2011), only a small range of single chemical extractants (e.g., EDTA, $\mathrm{CaCl}_{2}$ ) have been used to relate plant Co uptake with an operationally defined available concentration of extracted Co. Among 
these extractants, Faucon et al. (2009) have shown that the AA-EDTA extractable fraction is a reliable predictor of Co mobility and their latter uptake by hyperaccumulator plants in contaminated soils of south central Africa. Moreover, several studies have shown that AA-EDTA and EDTA are often considered to extract primarily organically bound trace elements from soil and not only elements nonspecifically adsorbed on the exchange complex (Albanese, 2008; Rupa and Shukla, 1999).

Scatter plots of $\log (\mathrm{Co}, \mathrm{Cu}, \mathrm{Zn})$ modeled as a function of $\log (\mathrm{Co}, \mathrm{Cu}, \mathrm{Zn})$ extractable are given in Figs. 2, 3 and 4 considering various modeling scenarios. In the first two conditions (Figs. 2a, 2b, 3a, 3b, 4a, 4b), Ca and Mg were considered as able to bind to SOM whereas in the last two conditions (Figs. 2c, 2d, 3c, 3d, 4c, 4d) they were not. The other varying parameter is the definition of metal modeled, in the first two conditions (Figs. 2a, 2c, 3a, 3c, 4a, 4c) modeled fractions only include divalent cations whereas in the last two conditions (Figs. 2b, 2d, 3b, 3d and 4b, 4d) modeled fractions consider the sum of divalent cations and organic species.

Considerable variation in the predicted speciation of the metals was observed (Table 3). Speciation calculations of Etoile samples indicate that Co and $\mathrm{Zn}$ will mostly occur as $\mathrm{Co}^{2+}$ and $\mathrm{Zn}^{2+}$ whereas $\mathrm{Cu}$ will mostly bind to Fe oxides. Speciation calculations for Niamumenda samples show more variation. Indeed, when assuming $\mathrm{Ca}$ and $\mathrm{Mg}$ bind to $\mathrm{HM}$, Co is mostly predicted as being bound to Mn oxide, whereas competition with $\mathrm{HM}$ occurs when $\mathrm{Ca}$ and $\mathrm{Mg}$ do not bind to $\mathrm{HM}$. Copper is predicted to occur as being bound to $\mathrm{Fe}$ oxide when $\mathrm{Ca}$ and $\mathrm{Mg}$ bind to $\mathrm{HM}$ whereas competition with HM occurs when $\mathrm{Ca}$ and $\mathrm{Mg}$ do not bind to HM. Zinc mostly occurs as divalent form when $\mathrm{Ca}$ and $\mathrm{Mg}$ bind to $\mathrm{HM}$ whereas competition with $\mathrm{HM}$ occurs when $\mathrm{Ca}$ and $\mathrm{Mg}$ do not bind to HM. Speciation calculations of Vallée Karavia and 
Ruashi samples show contrasted predictions depending on the considered scenarios. When considering $\mathrm{Ca}$ and $\mathrm{Mg}$ bind to $\mathrm{HM}, \mathrm{Co}, \mathrm{Cu}$ and $\mathrm{Zn}$ species are fractionated between Fe and Mn oxides, divalent cations and HM. By contrast, when considering $\mathrm{Ca}$ and $\mathrm{Mg}$ do not bind to $\mathrm{HM}, \mathrm{Co}, \mathrm{Cu}$ and $\mathrm{Zn}$ globally occur as organic species.

\section{Discussion}

\subsection{Modeling validation}

In order to discriminate between modeling scenarios, speciation modeling was compared to AA-EDTA extraction. The correlations between log metal modeled and $\log$ metal extractable were strongest for $\mathrm{Cu}$ and $\mathrm{Zn}$ when the model considers cationic forms and organic species as mobile fraction (Figs. $3 \mathrm{~b}$ and $4 \mathrm{~b} ; \mathrm{r}=0.92, p<0.001$ and $\mathrm{r}=0.73, p<0.001$, respectively) as regards to scenario where only divalent cations are considered as mobile (Figs. 3a, and 4a ; r $=0.85, p<0.001$ and $\mathrm{r}=0.49, p>0.1$ and thus not significant, respectively). By contrast, for Co there is no variation depending on the considered scenarios (Fig. $2 \mathrm{a}$ and $\mathrm{b} ; \mathrm{r}=0.92, p<0.001$ ). When the model was adjusted to remove $\mathrm{Ca}$ and $\mathrm{Mg}$ binding to $\mathrm{HM}$, thereby suppressing competition for the trace metals, the predicted binding with $\mathrm{HM}$ of the three metals increased (Table 3). The proportions of $\mathrm{Co}^{2+}, \mathrm{Cu}^{2+}$ and $\mathrm{Zn}^{2+}$ decreased significantly, while large gains were observed in the proportions of these metals bound to HM. Organic matter became the dominant binding species in most of the samples. There is better agreement between observations and modeling when $\mathrm{Ca}$ and $\mathrm{Mg}$ are not competing with Co for binding sites on the HM ( $\mathrm{r}=0.92$ vs 0.93 , with $\mathrm{p}$-values < 0.001). The agreement between observations and speciation modeling became slightly 
lower for $\mathrm{Cu}$ and $\mathrm{Zn}(\mathrm{r}=0.86$ vs 0.91 and 0.69 vs 0.73 , respectively, with p-values < 0.001) when $\mathrm{Ca}$ and $\mathrm{Mg}$ are not competing with metals for binding sites on $\mathrm{HM}$ surfaces. A paired Wilcoxon test was conducted on the differences between the two speciation modeling scenarios (i.e., considering or not $\mathrm{Ca}$ and $\mathrm{Mg}$ bind to $\mathrm{HM}$ ). Differences between the two data sets are only statistically significant for Co in Etoile and Ruashi sites $(\mathrm{p}<0.05)$. Eventually, in order to model the system as close as possible to a natural condition, the scenario considering $\mathrm{Ca}$ and $\mathrm{Mg}$ binding to $\mathrm{HM}$ and compete with metals should be selected. Moreover, cationic forms and organic species should be further considered as the mobile fraction.

It is obvious that depending on the chosen scenario, the speciation modeling will lead to different predictions. Moreover, it must be highlighted that authors of the model themselves have noted a number of possible pitfalls (Lofts and Tipping, 1998), detailed as follows. First, the generic constants used in the modeling represent an average of metal humic binding parameters determined in laboratory experiments with extracted HM (Ephraim et al., 1989). The behavior of SOM to sorb metals may be stronger than that considered and some assumptions (such as $50 \%$ of the SOM measured in the field samples is HM, themselves being defined as $100 \% \mathrm{HA}$ ) may be unrealistic. Indeed, Sparks (2003) proposed that $56 \%$ of the SOM is assumed to be $\mathrm{HM}$, and $84 \%$ and $16 \%$ of $\mathrm{HM}$ is defined as $\mathrm{HA}$ and FA, respectively. Considering cationic forms and organic species as mobile fraction and competition with $\mathrm{Ca}$ and $\mathrm{Mg}$, correlations between $\log$ metal modeled and $\log$ metal extractable were only slightly stronger for $\mathrm{Co}$ and $\mathrm{Cu}$ (Figs. 5 ; $\mathrm{r}=0.91$ and $\mathrm{r}=0.92$, for $\mathrm{Co}$ and $\mathrm{Cu}$, respectively, with p-values $<0.001$ ) when the model considers the distribution of SOM as proposed by Sparks (2003) and fells into the repeatability and error of modeling (Figs. $3 b$, and $4 b$; $r=0.92$ and $r=0.91$ for $\mathrm{Co}$ and $\mathrm{Cu}$, respectively, with $\mathrm{p}$ - 
values $<0.001)$. According to this sensitivity test, the use of the initial assumptions considering that $50 \%$ of the $\mathrm{SOM}$ is $\mathrm{HM}$, further defined as $100 \% \mathrm{HA}$, is a good approach. Moreover, the generic constants for Mn and Fe oxides used in the modeling and associated binding parameters were determined in laboratory not in field (Davis and Leckie, 1978; Pourret and Davranche, 2013; Tonkin et al., 2004). Secondly, competitive binding with $\mathrm{Fe}^{3+}$ or $\mathrm{Al}^{3+}$ in solution is known to affect markedly the extent of $\mathrm{Cu}$ complexation by $\mathrm{HM}$, due to the competition for the small proportion of very strong binding sites (Tipping, 2002; Unsworth et al., 2006). Albeit, in Katanga, the soil $\mathrm{pH}$ values rule out the presence of $\mathrm{Al}^{3+}$ in solution (Kabata-Pendias and Pendias, 2001). As a result, the competition between $\mathrm{Al}^{3+}$ and $\mathrm{Cu}^{2+}$ for binding sites does not have to be considered. Finally, the modeling consideration of metal binding to colloidal Fe and $\mathrm{Mn}$ oxides and heterogeneous metal binding to $\mathrm{HM}$ is likely to simplify considerably the true situation. The results from this work suggest that modeling can predict the distribution of dominant species of trace metals in soils with reasonable accuracy. However, concentrations of cationic species, when they represent a very small fraction of total concentrations, as for $\mathrm{Cu}$ in sample $\mathrm{E} 4$, may be under-estimated by several orders of magnitude (Unsworth et al., 2006). These uncertainties are concerning, given the current importance ascribed to cationic forms in models of biological uptake. This means that the model should be used with caution to assess other influences on metal fractionation, for instance availability to the biota or metallophyte plants (Allen, 1993; Faucon et al., 2012; Lange et al., 2014). Indeed, Lange et al. (2014) demonstrated that variation in $\mathrm{Cu}$ availability expressed by accumulation in plant shoots were mostly influenced by $\mathrm{Cu}$ sorbed by $\mathrm{Mn}$ and $\mathrm{Fe}$ oxide fractions, whereas Co availability variations were strongly influenced by divalent $\mathrm{Co}$ and Co sorbed by $\mathrm{OM}$ and Fe fractions. 


\subsection{Modeling application}

Except for these limitations and considering such modeling as a valid approach for $\mathrm{Co}$ and $\mathrm{Cu}$ speciation, variation of $\mathrm{Co}$ fractionation as regards to sites and thus to soil composition is significant (Table 4). Cobalt, $\mathrm{Cu}$ and $\mathrm{Zn}$ have been recognized as being more or less strongly mobilized by both the organic and inorganic colloidal phases (Bradl, 2004). Cobalt, $\mathrm{Cu}$ and $\mathrm{Zn}$ appeared to be sorbed by $\mathrm{Mn} / \mathrm{Fe}$ oxides and organic colloids and to have a small fraction occurring as truly dissolved species in soils or shallow groundwaters (Pédrot et al., 2008; Pourret et al., 2007b).

The high abundance of Mn particles (Faucon et al., 2007; 2009) and their large specific area and charge as well as their surface functional hydroxyl groups make mineral particles among the most important sorbents of $\mathrm{Co}$, and a competitor to HM. This is well expressed in the Niamumenda site where, for Mn content ranging from $1,856 \mathrm{mg} / \mathrm{kg}$ and $10,480 \mathrm{mg} / \mathrm{kg}$, Co is mostly bound to Mn oxide. Sample Nm2 shows a smaller fraction of $\mathrm{Co}$ bound to $\mathrm{Mn}$ oxide and a greater $\mathrm{Co}^{2+}$ fraction. This likely results from a higher competition with $\mathrm{Cu}$ (ca. 5 to 10 times more concentrated in the $\mathrm{Nm} 2$ soil than in other samples for binding sites of Fe and Mn oxides). In the Etoile site, fractionation of Co mostly occurs with Fe and Mn oxides and cationic form (at $\mathrm{pH}$ varying between 5.2 and 5.6), except for E4 samples for which Co is predominantly bound to $\mathrm{Fe}$ and $\mathrm{Mn}$ oxides (at $\mathrm{pH}$ 6.0). It can be thus inferred that $\mathrm{pH}$ is probably the most important parameter controlling metal speciation. Although the $\mathrm{pH}$ influence on the stability of colloids is well documented (e.g., Lead and Wilkinson, 2006), only a few studies investigated the effect of $\mathrm{pH}$ changes on the release of colloids and associated metals (Pédrot et al., 2008) and, thus on metal 
mobility/availability leading to accumulation in plants (e.g., Lange et al., 2014). In the two other sites (Vallée Karavia and Ruashi) which have been contaminated by atmospheric fallouts from the copper smelter of Lubumbashi, soils are mostly organic and contain low $\mathrm{Mn}$ and $\mathrm{Fe}$ contents. This explains that $\mathrm{Co}$ and $\mathrm{Cu}$ are fractionated between $\mathrm{HM}$ and cationic forms (i.e., $\mathrm{Co}^{2+}$ and $\mathrm{Cu}^{2+}$ ).

\subsection{Assessment on $\mathrm{Co}$ and $\mathrm{Cu}$ mobility and associated risks}

Unfortunately, as in many countries such as Morocco no environmental guidelines exist to regulate maximum permissible metal concentrations in soils or to give reference values above which action should be taken to mitigate environmental risk (Khalil et al., 2013). Therefore, the values from this study can be compared with guidelines adopted by Canada and European community as done by the group of Khalil et al. (2013). The results indicate that values of $\mathrm{Cu}$ (between 4,667 mg/kg and 17,255 mg/kg; Table 4), and Co (between $82 \mathrm{mg} / \mathrm{kg}$ and 4,889 mg/kg; Table 4) highly exceed the reference values. Moreover, Cheyns et al. (2014) proposed a background value for Co of $20 \mathrm{mg} / \mathrm{kg}$. According to these results, considering the total concentrations of $\mathrm{Cu}$ and $\mathrm{Co}$ in soils, such concentrations could have adverse health effects (Banza et al., 2009; Cheyns et al., 2014) especially on young children's health that has a higher absorption rate of metals because of their active digestion system. Past studies have revealed that $\mathrm{Cu}$ accumulation in human tissues may lead to Wilson's disease which causes liver disease and multiple organ dysfunctions and Co is known to cause hepatic glycogenolysis (Peplow and Edmonds, 2005). As evidenced by Cheyns et al. (2014), consumption of vegetables is the largest contributor to Co intake in adults, whereas dust and soil ingestion appeared to contribute substantially 
in children. Unlike recent study by Atibu et al. (2013), Mwanamoki et al. (2014), Narendrula et al. (2012, 2013), this study considers speciation modeling and thus allows us to get more details on metal fractionation and processes that control metal availability in soils. As evidenced by Leggett (2008) and Simonsen et al. (2012), the inorganic form of $\mathrm{Co}$ is the more toxic. Indeed, results indicate that values of inorganic $\mathrm{Cu}$ (between $469 \mathrm{mg} / \mathrm{kg}$ and 4,831 mg/kg; Table 4), and inorganic Co (between $49 \mathrm{mg} / \mathrm{kg}$ and 3,051 mg/kg; Table 4) still highly exceed the used reference values. Thus, the risks of contamination are high for people living close to mines or smelting plants (including the site contaminated by the $\mathrm{Cu}$-smelter industry of Lubumbashi) where consumption of vegetables or fish and dust or soil ingestion may lead to intakes of toxic level metals (Cheyns et al., 2014; Katemo Manda et al., 2010).

\subsection{Implication and perspectives for phytoremediation}

It is increasingly recognized that the metal availability can form the basis for evaluating potential risks that contaminants pose to the environment, and for determining remedial options to limit risks of contaminant dispersal and toxicity (Harmsen and Naidu, 2013). Indeed, phytoremediation studies and estimation of bioavailable metals use total metal concentrations or extractable metal concentrations determined at a fixed $\mathrm{pH}$ which may underestimate metal mobility (e.g., $\mathrm{AcNH}_{4}{ }^{-}$ EDTA $1 \mathrm{~mol} / \mathrm{L}$ at $\mathrm{pH}=4.65$; Brun et al., 1998; Faucon et al. 2009; Shutcha et al., 2010; or $\mathrm{LiNO}_{3}$ 0.01 mol/L; Abedin et al., 2012; Narendrula et al., 2013). Moreover, $\mathrm{pH}$ variations are not considered, while it highly influences metal mobility and availability (Alloway, 1995; Kabata-Pendias and Pendias, 2001; Faucon et al., 2011; Lange et al., 2014). Results from this study show that the metal speciation modeling 
in soils provides new insights into the processes that control metal availability in soils. These results can make possible to generate decision criteria for selecting appropriate remediation strategy.

In a phytoremediation perspective, sites with high $\mathrm{Co}^{2+}$ concentration, and thus high level of Co availability, could be treated by phytoremediation using Cotolerant species from the flora of $\mathrm{Cu}$-Co rocks outcrops (Faucon et al., 2010) or more specifically phytoextracted by Co hyperaccumulator species (Reeves and Baker, 2000; Faucon et al., 2007; Lange et al., 2014). On the other hand, sites with lower $\mathrm{Cu}$ Co inorganic concentrations could be economically valorized by the cultivation of $\mathrm{Cu}-\mathrm{Co}$ non-tolerant species with high biomass productivity, allowing bioenergy production (e.g., Nsanganwimana et al., 2013).

As these results demonstrate the ability of the model to assess the influence of several soil constituents (e.g., Fe-, Mn-oxides, SOM) on the metal availability, it could also potentially be used to predict the effects of soil amendments traditionally used in phytostabilization strategies, including organic matter (manure, compost, biochar) as well as Fe-, Mn-oxides (steel shots, iron grit, zero-valent Fe) (Houben et al., 2012; 2013; Lambrechts et al., 2011). In terms of a phytostabilization perspective, this model could be useful for driving the selection of amendments and the choice of plant species according to their degree of metal tolerance (Faucon et al., 2012; Lange et al., 2014). Indeed, a more detailed understanding of Co fractionation in soils is necessary to appreciate the high variation of Co availability and related concentrations in plants growing on metalliferous soils (Collins and Kinsela, 2011; Lange et al., 2014). The $\mathrm{Cu}$ and $\mathrm{Co}$ fractionation is illustrated in Table 4 where differences between sites are clearly highlighted. 
Nevertheless, the speciation model in its current version provides no information about the potential metal phytotoxicity. To overcome this issue, WHAM 6 could be combined with biotic ligand models (BLM) that are useful proxies to assess metal toxicity not only for aquatic systems but also for terrestrial plants (Lock et al., 2007). Using BLM, Lock et al. (2007) showed for instance that Co toxicity to barley increases with increasing activities of $\mathrm{Mg}^{2+}$ and, to a lesser extent $\mathrm{K}^{+}$, while it is not affected by variation of $\mathrm{Ca}^{2+}, \mathrm{Na}^{+}$and $\mathrm{H}^{+}$activities. The use of BLM to estimate the soil phytotoxicity could thus refine the selection of plants that are suitable for phytoremediation of metal contaminated sites. More recently, Tipping and Loft (2014) proposed a new model, WHAM-F $F_{\text {TOX }}$, which describes cation toxicity to aquatic organisms in terms of accumulation by organism of metabolically-active metals at reversible sites, and differing toxic potencies of the bound cations.

\section{Concluding remarks}

In the present study, the mobility and resulting availability of metals was assessed using the application of both AA-EDTA extraction and speciation modeling (WHAM 6) to organic-rich soils contaminated by trace metals in the Copperbelt of Upper Katanga (Democratic Republic of Congo). The resulting data set covers wide ranges of conditions ( $\mathrm{pH}$, trace metals concentration, natural and anthropogenic soils) enabling comparisons between extraction and speciation modeling. Good agreement between the observations and model predictions (especially for $\mathrm{Co}$ and $\mathrm{Cu}$ ) supports the validity of both approaches.

Speciation calculation results were further considered to evaluate more precisely metal speciation and gain insights into the variability between sites 
considering or not major competitors (i.e., $\mathrm{Ca}$ and $\mathrm{Mg}$ ). When the model was adjusted to remove major competitors binding and their competition with other metals, the predicted binding with $\mathrm{HM}$ of the studied metals (i.e., $\mathrm{Co}, \mathrm{Cu}$ and $\mathrm{Zn}$ ) increased. The extent of major cation competition is thus of potential significance. Thus to model the system as close as possible to natural and field conditions, major cation competition with metals should be selected. In general, our results are promising in that they demonstrate the importance of approaching the metal fractionation in soils using modeling to improve knowledge on metal availability and mobility in soils.

The modeling of metal fractionation might be interesting to identify the factors responsible for metal partitioning, and to predict metal availability, thereby turning out to be a useful decision tool to guide the choices of phytoremediation practices. Cationic $\mathrm{Co}$ and $\mathrm{Cu}$ concentrations and the differences of $\mathrm{Cu}$ and $\mathrm{Co}$ soil speciation among sites could lead to a different approach in phytoremediation strategies: choice of plant species (degree of $\mathrm{Cu}$ and/or Co tolerant or non tolerant species), quality and quantity of organic amendments.

\section{ACKNOWLEDGMENTS}

The authors thank the Institut Polytechnique LaSalle Beauvais, France, for funding MS mobility and BL MSc project. Dr Victor Acha is acknowledged for post-editing the English content. The authors would like to thank the two anonymous reviewers and editor for their constructive comments. 


\section{Table and Figure Captions}

Table 1. Location and description of study sites. All sites are in Upper Katanga (Democratic Republic of Congo). Coordinates are in GCS WGS84 (DD).

Table 2. $\mathrm{pH}$, soil organic matter in $\%$ and metal concentrations in $\mathrm{mg} / \mathrm{kg}$ soil.

Table 3. Speciation modeling (expressed in \%), assuming $\mathrm{Ca}$ and $\mathrm{Mg}$ bind to $\mathrm{HM}$ and then assuming $\mathrm{Ca}$ and $\mathrm{Mg}$ do not bind to $\mathrm{HM} .50 \%$ of the SOM is assumed to be HM and $100 \%$ being defined as HA.

Table 4. Copper and Co concentrations in soil (mg/kg) among sites. Significance: **: $\mathrm{p}<0.01, *: \mathrm{p}<0.05, \mathrm{NS}=$ non-significant. Variables with the same letter above are not significantly different among sites (results of Kruskall Wallis test). $-\mathrm{HM}=$ bound to humic material $-\mathrm{MnOx}=$ bound to manganese oxides, $-\mathrm{FeOx}=$ bound to iron oxides, $\mathrm{sd}=$ standard deviation.

Figure 1. Scatter plot of log total metal concentration as a function of log extractable concentration for (a) $\mathrm{Co}$, (b) $\mathrm{Cu}$ and (c) $\mathrm{Zn}$.

Figure 2. Scatter plot of $\log$ extractable concentration of Co as a function of (a) $\log$ modeled $\mathrm{Co}^{2+}$ considering $\mathrm{Ca}$ and $\mathrm{Mg}$ bind to $\mathrm{HM}$, (b) $\log$ modeled $\mathrm{Co}^{2+}+\mathrm{Co}-\mathrm{HM}$ considering $\mathrm{Ca}$ and $\mathrm{Mg}$ bind to $\mathrm{HM}$, (c) $\log$ modeled $\mathrm{Co}^{2+}$ considering $\mathrm{Ca}$ and $\mathrm{Mg}$ do not bind to $\mathrm{HM}$, (d) $\log$ modeled $\mathrm{Co}^{2+}+\mathrm{Co}-\mathrm{HM}$ considering $\mathrm{Ca}$ and $\mathrm{Mg}$ do not bind to $\mathrm{HM} ; 50 \%$ of the SOM is assumed to be $\mathrm{HM}$ and $100 \%$ being defined as HA. 
Figure 3. Scatter plot of $\log$ extractable concentration of $\mathrm{Cu}$ as a function of (a) $\log$ modeled $\mathrm{Cu}^{2+}$ considering $\mathrm{Ca}$ and $\mathrm{Mg}$ bind to $\mathrm{HM}$, (b) log modeled $\mathrm{Cu}^{2+}+\mathrm{Cu}-\mathrm{HM}$ considering $\mathrm{Ca}$ and $\mathrm{Mg}$ bind to $\mathrm{HM}$, (c) $\log$ modeled $\mathrm{Cu}^{2+}$ considering $\mathrm{Ca}$ and $\mathrm{Mg}$ do not bind to $\mathrm{HM}$, (d) $\log$ modeled $\mathrm{Cu}^{2+}+\mathrm{Cu}-\mathrm{HM}$ considering $\mathrm{Ca}$ and $\mathrm{Mg}$ do not bind to HM; $50 \%$ of the SOM is assumed to be HM and $100 \%$ being defined as HA.

Figure 4. Scatter plot of $\log$ extractable concentration of $\mathrm{Zn}$ as a function of (a) $\log$ modeled $\mathrm{Zn}^{2+}$ considering $\mathrm{Ca}$ and $\mathrm{Mg}$ bind to $\mathrm{HM}$, (b) log modeled $\mathrm{Zn}^{2+}+\mathrm{Zn}-\mathrm{HM}$ considering $\mathrm{Ca}$ and $\mathrm{Mg}$ bind to $\mathrm{HM}$, (c) $\log$ modeled $\mathrm{Zn}^{2+}$ considering $\mathrm{Ca}$ and $\mathrm{Mg}$ do not bind to $\mathrm{HM}$, (d) $\log$ modeled $\mathrm{Zn}^{2+}+\mathrm{Zn}-\mathrm{HM}$ considering $\mathrm{Ca}$ and $\mathrm{Mg}$ do not bind to $\mathrm{HM} ; 50 \%$ of the SOM is assumed to be HM and $100 \%$ being defined as HA.

Figure 5. Scatter plot of (a) $\log$ extractable concentration of Co as a function of log modeled $\mathrm{Co}^{2+}+\mathrm{Co}-\mathrm{HM}$ and (b) $\log$ extractable concentration of $\mathrm{Cu}$ as a function of $\log$ modeled $\mathrm{Cu}^{2+}+\mathrm{Cu}-\mathrm{HM}$, considering $\mathrm{Ca}$ and $\mathrm{Mg}$ bind to $\mathrm{HM} ; 56 \%$ of the $\mathrm{SOM}$ is assumed to be HM and $84 \%$ and $16 \%$ being defined as HA and FA, as proposed by Sparks (2003). 


\section{REFERENCES}

Abedin, J., Beckett, P., Spiers, G., 2012. An evaluation of extractants for assessment of metal phytoavailability to guide reclamation practices in acidic soilscapes in northern regions. Canadian Journal of Soil Science 92 (1), 253-268.

AFNOR (Ed.), 2001. Qualité du sol. Mise en solution pour la détermination des teneurs élémentaires totales. Partie 1: Mise en solution par l'acide fluorhydrique et l'acide perchlorique. NF ISO 14869-1.

Albanese, S., De Vivo, B., Lima, A., Cicchella, D., 2007. Geochemical background and baseline values of toxic elements in stream sediments of Campania region (Italy). Journal of Geochemical Exploration, 93 (1), 21-34.

Albanese, S., 2008. Evaluation of the bioavailability of potentially harmful elements in urban soils through ammonium acetate-EDTA extraction: a case study in southern Italy. Geochemistry: Exploration, Environment, Analysis 8(1), 4957.

Allen, H.E., 1993. The significance of trace metal speciation for water, sediment and soil quality criteria and standards. Science of the Total Environment 134, Supplement 1(0), 23-45.

Alloway, B.J., 1995. Heavy Metals in Soils, 2nd ed. Blackie Academic and Professional, London.

Atibu, E.K., Devarajan, N., Thevenon, F., Mwanamoki, P.M., Tshibanda, J.B., Mpiana, P.T., Prabakar, K., Mubedi, J.I., Wildi, W., Poté, J., 2013. Concentration of metals in surface water and sediment of Luilu and Musonoie Rivers, Kolwezi-Katanga, Democratic Republic of Congo. Applied Geochemistry, 39, 26-32.

Banza, C.L.N., Nawrot, T.S., Haufroid, V., Decrée, S., De Putter, T., Smolders, E., Kabyla, B.I., Luboya, O.S., Ilunga, A.N., Mutombo, A.M., Nemery, B., 2009. High human exposure to cobalt and other metals in Katanga, a mining area of the Democratic Republic of Congo. Environmental Research, 109, 745-752.

Benedetti, M.F., Van Riemsdijk, W.H., Koopal, L.K., 1996. Humic substances considered as a heterogeneous Donnan gel phase. Environmental Science and Technology 30, 1805-1813.

Bradl, H.B., 2004. Adsorption of heavy metal ions on soils and soils constituents. Journal of Colloid and Interface Science 277 (1), 1-18.

Brun, L.A., Maillet, J., Richarte, J., Herrmann, P., Remy, J.C., 1998. Relationships between extractable copper, soil properties and copper uptake by wild plants in vineyard soils. Environmental Pollution, 102 (2-3), 151-161.

Cicchella, D., De Vivo, B., Lima, A., 2005. Background and baseline concentration values of elements harmful to human health in the volcanic soils of the metropolitan and provincial areas of Napoli (Italy). Geochemistry: Exploration, Environment, Analysis, 5 (1), 29-40.

Cheyns, K., Banza Lubaba Nkulu, C., Ngombe, L.K., Asosa, J.N., Haufroid, V., De Putter, T., Nawrot, T., Kimpanga, C.M., Numbi, O.L., Ilunga, B.K., Nemery, B., Smolders, E., 2014. Pathways of human exposure to cobalt in Katanga, a mining area of the D.R. Congo. Science of the Total Environment, 490, 313321.

Collins, R.N., Kinsela, A.S., 2011. Pedogenic factors and measurements of the plant uptake of cobalt. Plant and Soil 339, 499-512.

Davis, J.A., Leckie, J.O., 1978. Surface ionization and complexation at the oxide/water interface II. Surface properties of amorphous iron oxyhydroxide 
and adsorption of metal ions. Journal of Colloid and Interface Science 67 (1), 90-107.

Dean, J.R., 2007. Bioavailability, Bioaccessibility and Mobility of Environmental Contaminants. Analytical Techniques in the Sciences. Wiley, Chichester.

Decrée, S., Deloule, E., Ruffet, G., Dewaele, S., Mees, F., Marignac, C., Yans, J., De Putter, T., 2010. Geodynamic and climate controls in the formation of MioPliocene world class oxidized cobalt and manganes ores in the Katanga province, DR Congo. Mineralium Deposita 45, 621-629.

Ephraim, J.H., Marinsky, J.A., Cramer, S.J., 1989. Complex-forming properties of natural organic acids: Fulvic acid complexes with cobalt, zinc and europium. Talanta 36 (4), 437-443.

Faucon, M.-P., Parmentier, I., Colinet, G., Mahy, G., Ngongo Luhembwe, M., Meerts, P., 2011. May Rare Metallophytes Benefit from Disturbed Soils Following Mining Activity? The Case of the Crepidorhopalon tenuis in Katanga (D. R. Congo). Restoration Ecology 19 (3), 333-343.

Faucon, M.P., Chipeng, F., Verbruggen, N., Mahy, G., Colinet, G., Shutcha, M., Pourret, O., Meerts, P., 2012. Copper tolerance and accumulation in two cuprophytes of South Central Africa: Crepidorhopalon perennis and C. tenuis (Linderniaceae). Environmental and Experimental Botany 84, 11-16.

Faucon, M.P., Colinet, G., Mahy, G., Ngongo Luhembwe, M., Verbruggen, N., Meerts, P., 2009. Soil influence on $\mathrm{Cu}$ and $\mathrm{Co}$ uptake and plant size in the cuprophytes Crepidohopalon perennis and C. tenuis (Scophulariaceae) in SC Africa. Plant and Soil 317, 201-212.

Faucon, M.P., Shutcha, M.N., Meerts, P., 2007. Revisiting copper and cobalt concentrations in supposed hyperaccumilators from SC Africa: influence of washing and metal concentrations in soil. Plant and Soil 301, 29-36.

Giaccio, L., Cicchella, D., De Vivo, B., Lombardi, G., De Rosa, M., 2012. Does heavy metals pollution affects semen quality in men? A case of study in the metropolitan area of Naples (Italy). Journal of Geochemical Exploration, 112, 218-225.

Guillén, M.T., Delgado, J., Albanese, S., Nieto, J.M., Lima, A., De Vivo, B., 2011. Environmental geochemical mapping of Huelva municipality soils (SW Spain) as a tool to determine background and baseline values. Journal of Geochemical Exploration, 109 (1-3), 59-69.

Guillén, M.T., Delgado, J., Albanese, S., Nieto, J.M., Lima, A., De Vivo, B., 2012. Heavy metals fractionation and multivariate statistical techniques to evaluate the environmental risk in soils of Huelva Township (SW Iberian Peninsula). Journal of Geochemical Exploration, 119-120, 32-43.

Harmsen, J., Naidu, R., 2013. Bioavailability as a tool in site management. Journal of Hazardous Materials, 261, 840-846.

Hering, J.G., Morel, F.M., 1996. Humic acid complexation of calcium and copper. Environ. Sci. Technol. 22, 1234-1237.

Houben, D., Sonnet, P., 2012. Zinc mineral weathering as affected by plant roots. Applied Geochemistry 27, 1587-1592.

Houben, D., Pircar, J., Sonnet, P., 2012. Heavy metal immobilization by costeffective amendments in a contaminated soil: Effects on metal leaching and phytoavailability. Journal of Geochemical Exploration 123, 87-94.

Kabata-Pendias, A., Mukherjee, A.B., 2007. Trace Elements from Soil to Human. Springer, Berlin. 
Kabata-Pendias, A., Pendias, H., 2001. Trace Elements in Soils and Plants - Third Edition. CRC Press, Boca Raton.

Katemo Manda, B., Colinet, G., André, L., Chocha Manda, A., Marquet, J.-P., Micha, J.-C., 2010. Evaluation de la contamination de la chaîne trophique par les éléments traces $(\mathrm{Cu}, \mathrm{Co}, \mathrm{Zn}, \mathrm{Pb}, \mathrm{Cd}, \mathrm{U}, \mathrm{V}$ et $\mathrm{As})$ dans le bassin de la Lufira supérieure (Katanga, RD Congo). Tropicultura 28, 246-252 (in french).

Khalil, A., Hanich, L., Bannari, A., Zouhri, L., Pourret, O., Hakkou, R., 2013. Assessment of soil contamination around an abandoned mine in a semi-arid environment using geochemistry and geostatistics: Pre-work of geochemical process modeling with numerical models. Journal of Geochemical Exploration, 125, 117-129.

Kinniburgh, D.G., Milne, C.J., Benedetti, M.F., Pinheiro, J.P., Filius, J.D., Koopal, L.K., van Riemsdijk, W.H., 1996. Metal ion binding by humic acid: Application of the NICA-Donnan Model. Environmental Science and Technology 30, 1687-1698.

Lambrechts, T., Gustot, Q., Couder, E., Houben, D., Iserentant, A., Lutts, S., 2011. Comparison of EDTA-enhanced phytoextraction and phytostabilisation strategies with Lolium perenne on a heavy metal contaminated soil. Chemosphere 85, 1290-1298.

Lange, B., Faucon, M.-P., Meerts, P., Shutcha, M., Mahy, G., Pourret, O., 2014. Prediction of the edaphic factors influence upon the copper and cobalt accumulation in two metallophytes using copper and cobalt speciation in soils. Plant and Soil, 379, 275-287.

Leggett, R.W., 2008. The biokinetics of inorganic cobalt in the human body. Science of the Total Environment 389, 259-269.

Lock, K., De Schamphelaere, K.A.C., Becaus, S., Criel, P., Van Eeckhout, H., Janssen, C.R., 2007. Development and validation of a terrestrial biotic ligand model predicting the effect of cobalt on root growth of barley (Hordeum vulgare). Environmental Pollution 147(3), 626-633.

Lofts, S., Tipping, E., 1998. An assemblage model for cation binding by natural particulate matter. Geochimica et Cosmochimica Acta 62, 2609-2625.

Mwanamoki, P.M., Devarajan, N., Thevenon, F., Birane, N., de Alencastro, L.F., Grandjean, D., Mpiana, P.T., Prabakar, K., Mubedi, J.I., Kabele, C.G., Wildi, W., Poté, J., 2014. Trace metals and persistent organic pollutants in sediments from river-reservoir systems in Democratic Republic of Congo (DRC): Spatial distribution and potential ecotoxicological effects. Chemosphere, 111, 485492.

Narendrula, R., Nkongolo, K.K., Beckett, P., 2012. Comparative Soil Metal Analyses in Sudbury (Ontario, Canada) and Lubumbashi (Katanga, DR-Congo). Bulletin of Environmental Contamination and Toxicology, 88 (2), 187-192.

Narendrula, R., Nkongolo, K.K., Beckett, P., Spiers, G., 2013. Total and bioavailable metals in two contrasting mining regions (Sudbury in Canada and Lubumbashi in DR-Congo): relation to genetic variation in plant populations. Chemistry and Ecology, 29 (2), 111-127.

Nsanganwimana, F., Marchand, L., Douay, F., Mench, M., 2014. Arundo donax L., a candidate for phytomanaging water and soils contaminated by trace elements and producing plant-based feedstock. A review. International Journal of Phytoremediation 16, 982-1017. 
Pédrot, M., Dia, A., Davranche, M., Bouhnik-Le Coz, M., Henin, O., Gruau, G., 2008. Insights into colloid-mediated trace element release at the soil/water interface. Journal of Colloid and Interface Science 325, 187-197.

Peplow, D., Edmonds, R., 2005. The effects of mine waste contamination at multiple levels of biological organization. Ecological Engineering 24, 101-119.

Peters, R.W., 1999. Chelant extraction of heavy metals from contaminated soils. Journal of Hazardous Materials 66, 151-210.

Ponizovsky, A.A., Thakali, S., Allen, H.E., Di Toro, D.M., Ackerman, A.J., 2006. Effect of soil properties on copper release in soil solutions at low moisture content. Environmental Toxicology and Chemistry 25 (3), 671-682.

Pourret, O., Davranche, M., 2013. Rare earth element sorption onto hydrous manganese oxide A modeling study. Journal of Colloid and Interface Science 395, 18-23.

Pourret, O., Davranche, M., Gruau, G., Dia, A., 2007a. Organic complexation of rare earth elements in natural waters: Evaluating model calculations from ultrafiltration data. Geochimica et Cosmochimica Acta 71, 2718-2735.

Pourret, O., Dia, A., Davranche, M., Gruau, G., Hénin, O., Angée, M., 2007b. Organo-colloidal control on major- and trace-element partitioning in shallow groundwaters: confronting ultrafiltration and modelling. Applied Geochemistry 22, 1568-1582.

Reeder, R.J., Schoonen, M.A.A., Lanzirotti, A., 2006. Metal speciation and its role in bioaccessibility and bioavailability. Reviews in Mineralogy \& Geochemistry 64, 59-113.

Reeves, R.D., Baker, A.J.M., 2000. Metal-accumulating plants, in: Raskin, I., Ensley, B.D. (Eds.), Phytoremediation of toxic metals. Wiley, New York, USA, pp. 193-221.

Rupa, T.R., Shukla, L.M., 1999. Comparison of four extractants and chemical fractions for assessing available zinc and copper in soils of India. Communications in Soil Science and Plant Analysis 30 (19-20), 2579-2591.

Shutcha, M.N., Mubemba, M.M., Faucon, M.P., Luhembwe, M.N., Visser, M., Colinet, G., Meerts, P., 2010. Phytostabilisation of copper-contaminated soil in Katanga: An experiment with three native grasses and two amendments. International Journal of Phytoremediation 12, 616-632.

Simonsen, L.O., Harbak, H., Bennekou, P., 2012. Cobalt metabolism and toxicology-A brief update. Science of the Total Environment 432, 210-215.

Smith, K.S., Huyck, H.L.O., 1999. An overview of the abundance, relative mobility, bioavailability, and human toxicity of metals. In: G.S. Plumlee, M.J. Logsdon (Eds.), The Environmental Geochemistry of Mineral Deposits. Society of Economic Geologists, pp. 29-70.

Sparks, D.L., 2003. 3 - Chemistry of Soil Organic Matter. In: D.L. Sparks (Ed.), Environmental Soil Chemistry (Second Edition). Academic Press, Burlington, pp. $75-113$.

Tipping, E., 1994. WHAM - A chemical equilibrium model and computer code for waters, sediments, and soils incorporating a discrete site/electrostatic model of ion-binding by humic substances. Computer \& Geosciences 20,973-1023.

Tipping, E., 1998. Humic Ion-Binding Model VI: an improved description of the interactions of protons and metal ions with humic substances. Aquatic Geochemistry 4, 3-48.

Tipping, E., 2002. Cation binding by humic substances. University Press, Cambridge. 
Tipping, E., Rieuwerts, J., Pan, G., Ashmore, M.R., Lofts, S., Hill, M.T.R., Farago, M.E., Thornton, I., 2003. The solid-solution partitioning of heavy metals $(\mathrm{Cu}$, $\mathrm{Zn}, \mathrm{Cd}, \mathrm{Pb}$ ) in upland soils of England and Wales. Environmental Pollution $125,213-225$.

Tipping, E. and Lofts, S., 2014. Testing WHAM-F Tox with laboratory toxicity data for mixtures of metals $(\mathrm{Cu}, \mathrm{Zn}, \mathrm{Cd}, \mathrm{Ag}, \mathrm{Pb})$. Environmental Toxicology and Chemistry, DOI: 10.1002/etc.2773.

Tonkin, J.W., Balistrieri, L.S., Murray, J.W., 2004. Modeling sorption of divalent metal cations on hydrous manganese oxide using the diffuse double layer model. Applied Geochemistry 19, 29-53.

Unsworth, E.R., Warnken, K.W., Zhang, H., Davison, W., Black, F., Buffle, J., Cao, J., Cleven, R., Galceran, J., Gunkel, P., Kalis, E., Kistler, D., Van Leeuwen, H.P., Martin, M., Noël, S., Nur, Y., Odzak, N., Puy, J., Van Riemsdijk, W., Sigg, L., Temminghoff, E., Tercier-Waeber, M.-L., Toepperwien, S., Town, R.M., Weng, L., Xue, H., 2006. Model predictions of metal speciation in freshwaters compared to measurements by in situ techniques. Environmental Science and Technology 40, 1942-1949.

USGS, 2014. Mineral Commodity Summaries 2014. 

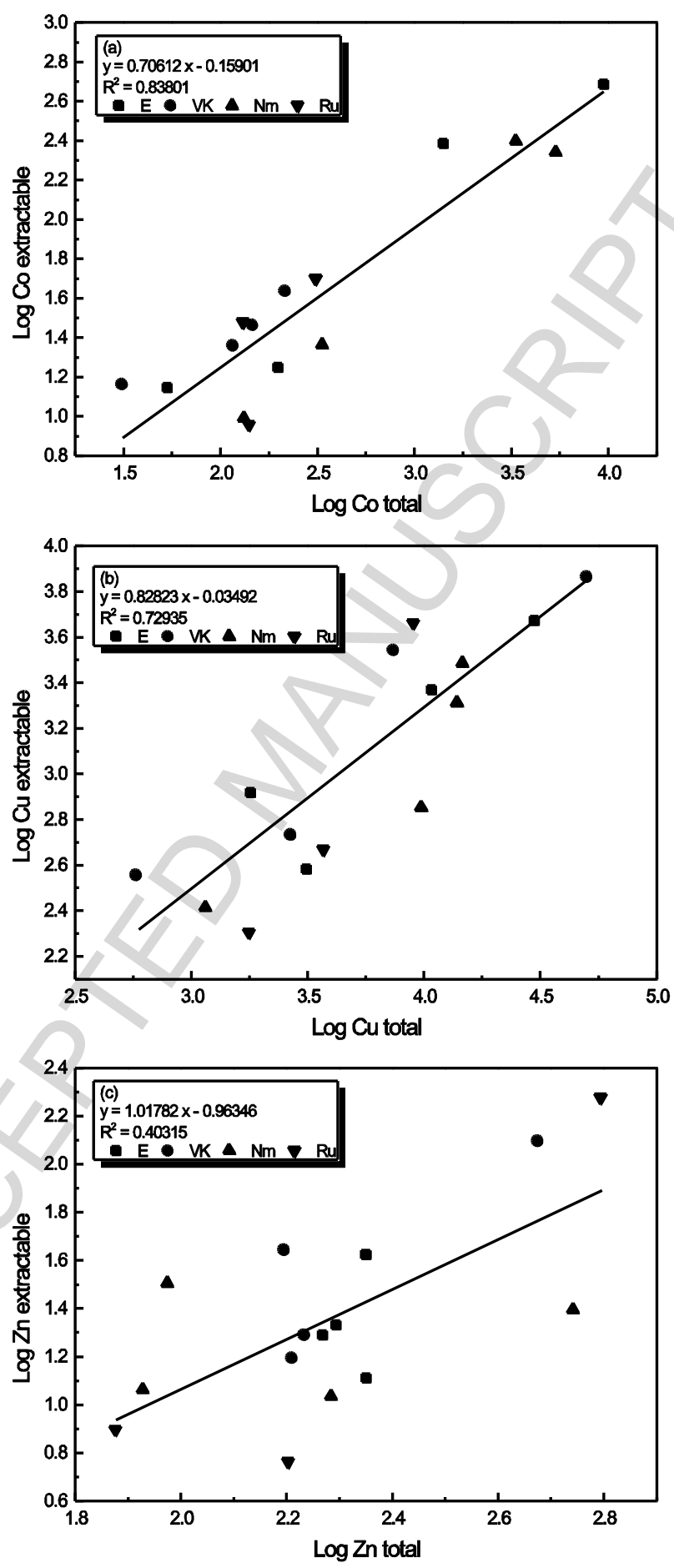

Fig. 1 

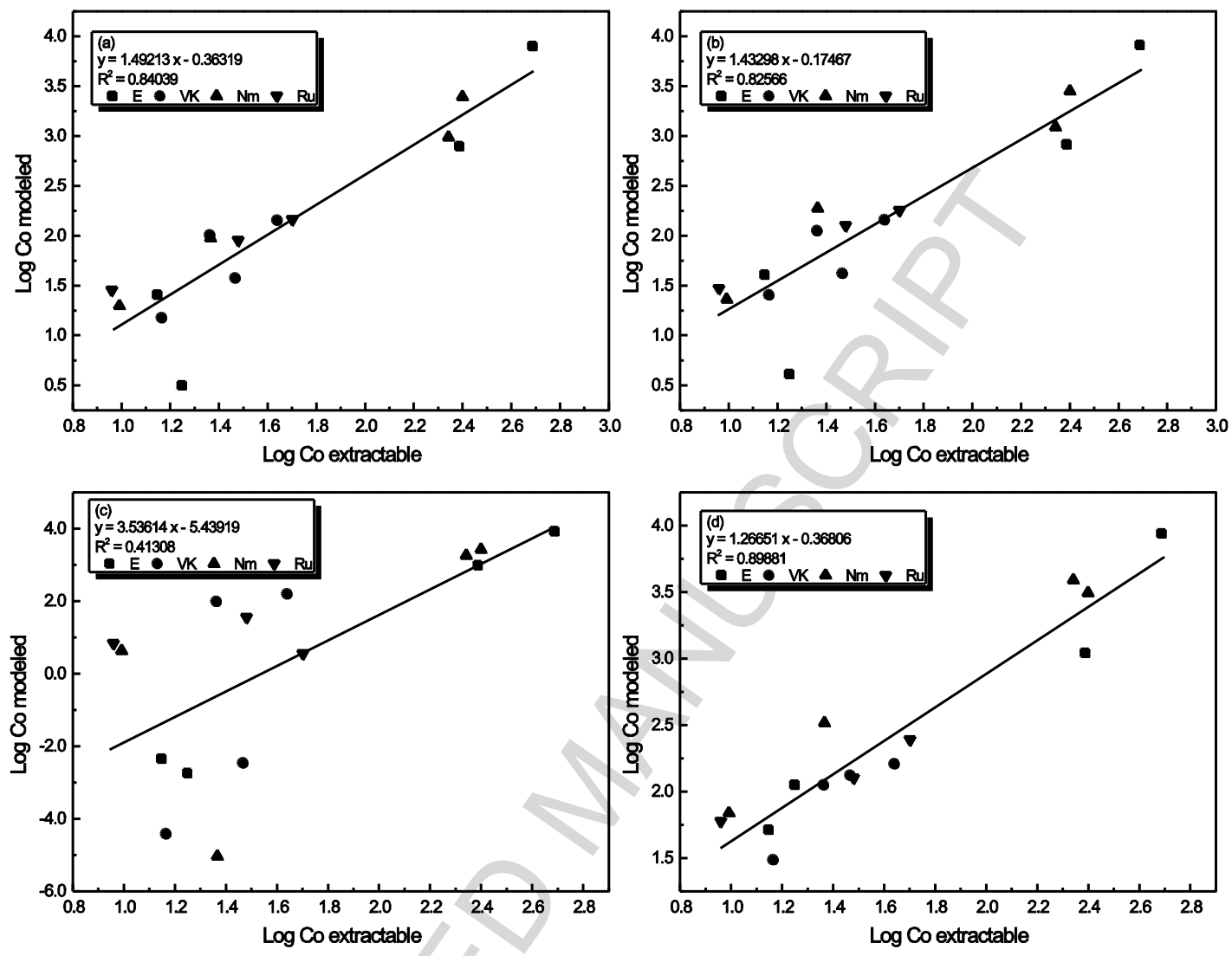

Fig. 2 

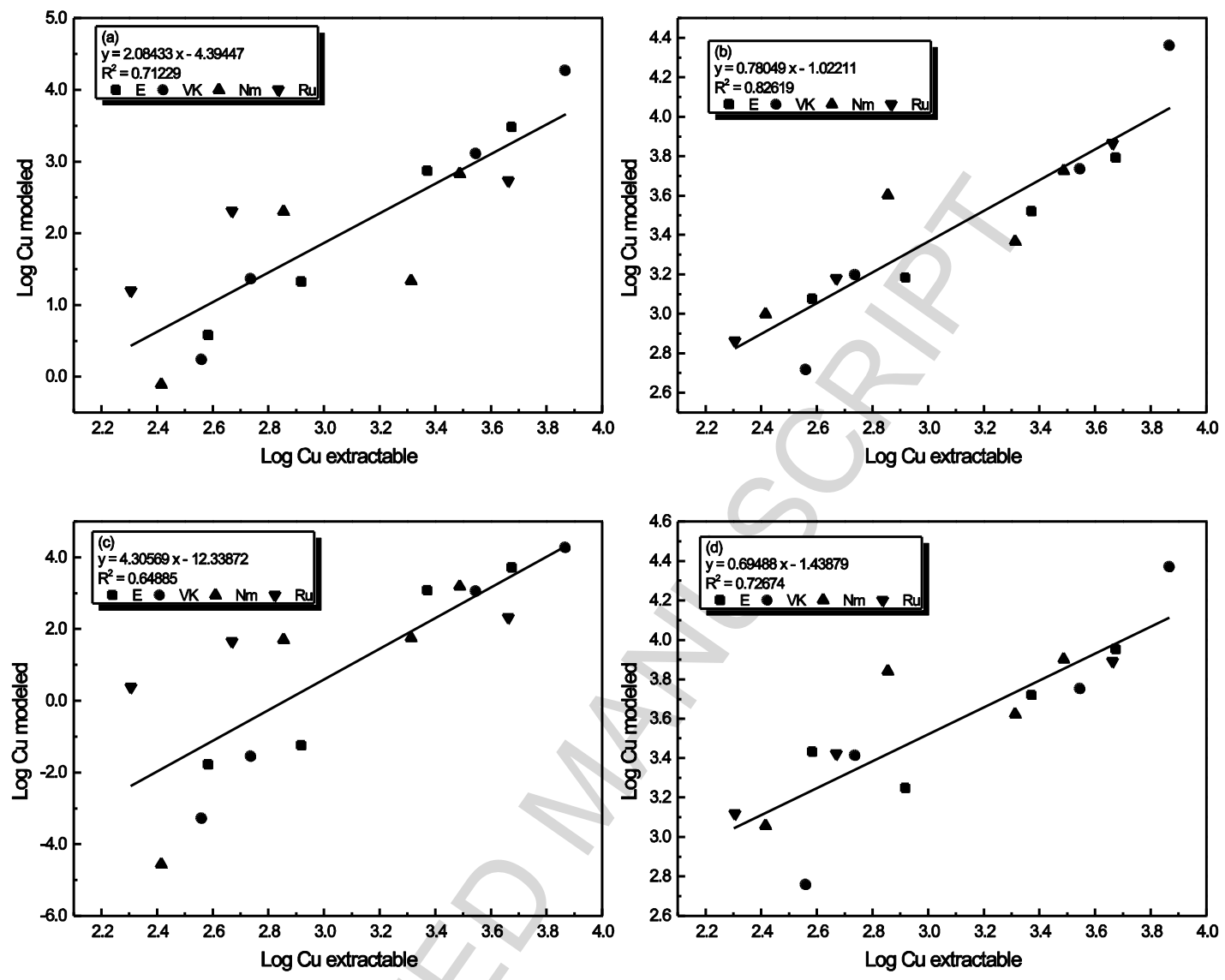

Fig. 3 

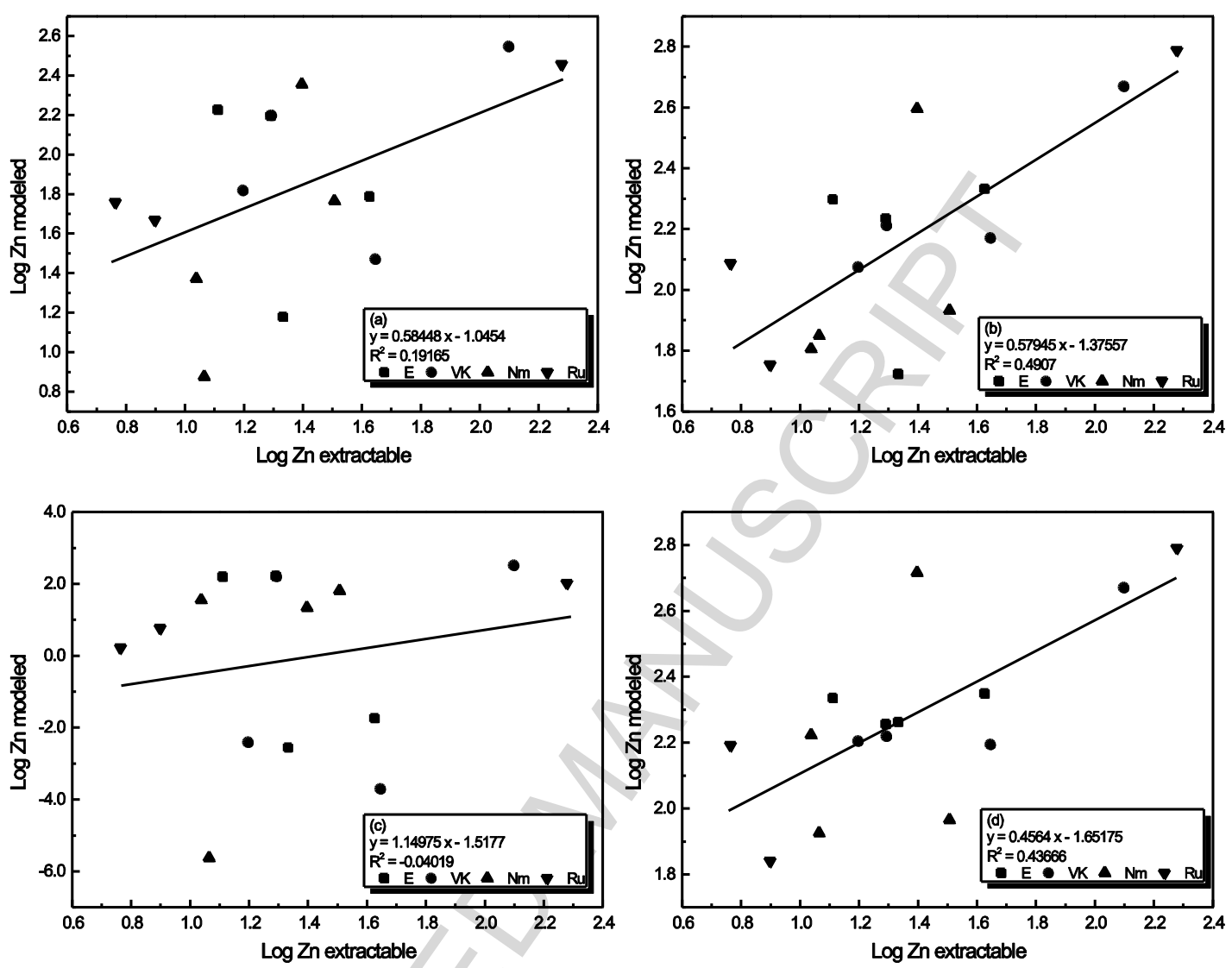

Fig. 4 

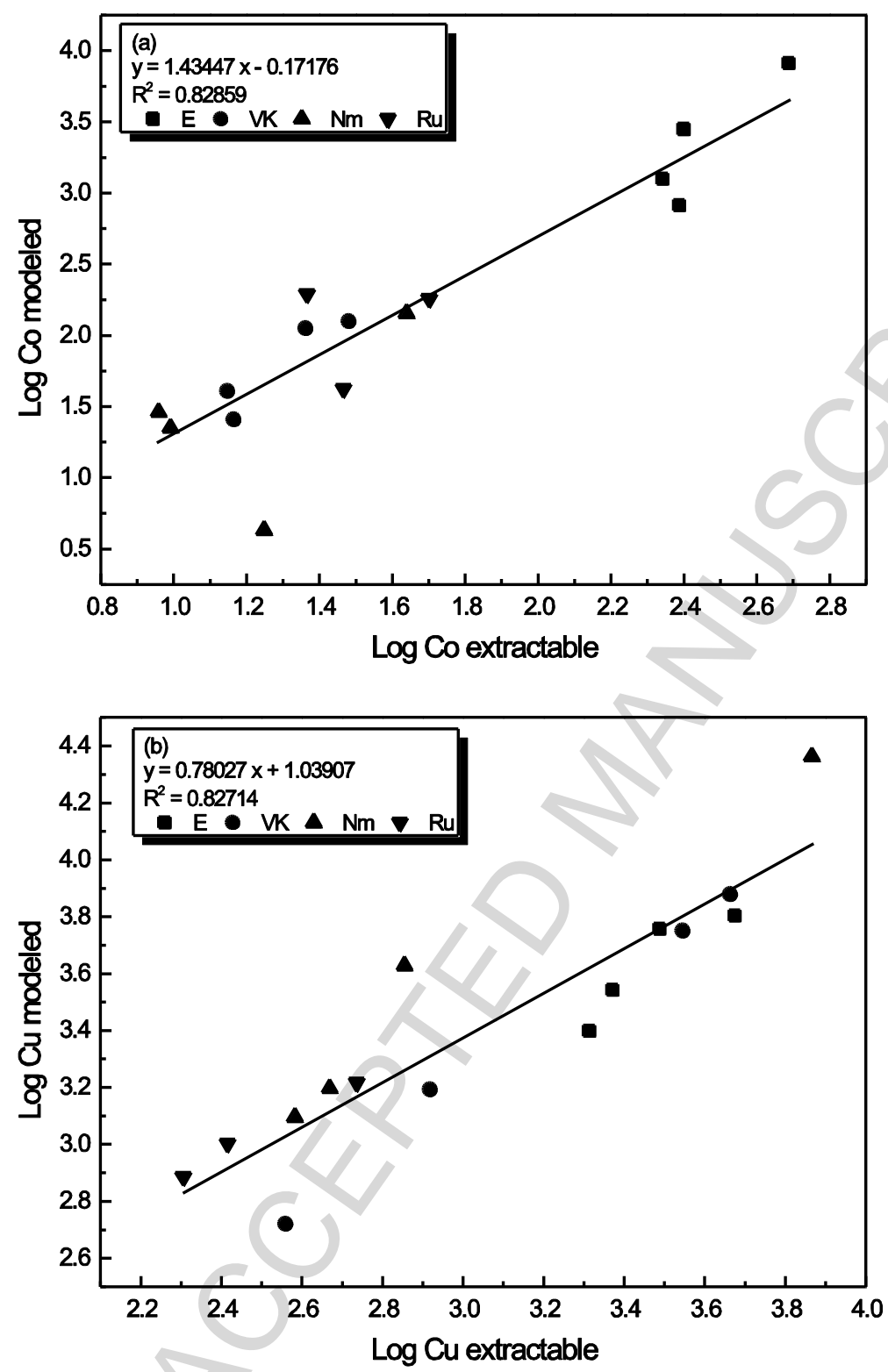

Figure 5 


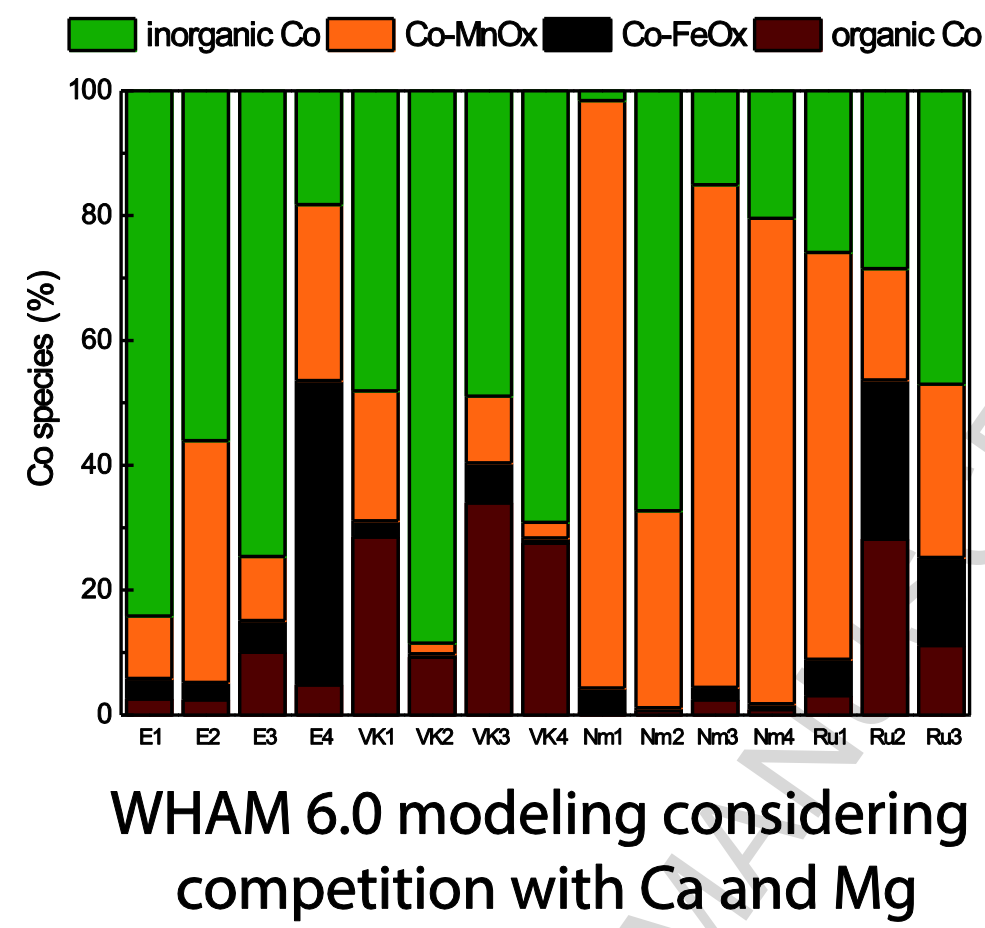

Graphical abstract 


\section{Table 1}

\begin{tabular}{cccc}
\hline Sites & Soil description & $\begin{array}{c}\text { Elevation } \\
\mathrm{m}\end{array}$ & Coordinates \\
\hline $\begin{array}{c}\text { Etoile } \\
(\mathrm{E})\end{array}$ & Natural copper hill; substrate locally disturbed by \\
mining (open pit) & 1280 & $\begin{array}{c}\mathrm{S} 11.63562^{\circ} \\
\mathrm{E} 27.58448^{\circ}\end{array}$ \\
$\begin{array}{c}\text { Niamumenda } \\
(\mathrm{Nm})\end{array}$ & Natural copper hill; substrate locally disturbed by \\
mining & 1340 & $\mathrm{~S} 11.60492^{\circ}$ \\
Vallée & Anthropogenic site: soil contaminated by & & $\mathrm{E} 27.29400^{\circ}$ \\
Karavia & atmospheric fall out from ore-smelter, moist & 1230 & $\mathrm{~S} 11.67270^{\circ}$ \\
$(\mathrm{VK})$ & environment & & $\mathrm{E} 27.43091^{\circ}$ \\
Ruashi & Anthropogenic site: recolonization of mineral \\
$(\mathrm{Ru})$ & deposits & 1300 & $\mathrm{~S} 11.62645^{\circ}$ \\
& & & $\mathrm{E} 27.56328^{\circ}$ \\
\hline
\end{tabular}


Table 2.

\begin{tabular}{|c|c|c|c|c|c|c|c|c|c|c|c|}
\hline $\begin{array}{l}\text { Sam } \\
\text { ple }\end{array}$ & $\begin{array}{l}\mathrm{p} \\
\mathrm{H}\end{array}$ & $\begin{array}{c}\% \\
\text { SOM }\end{array}$ & $\mathrm{Fe}$ & $\mathrm{Mn}$ & $\mathrm{K}$ & $\mathrm{Mg}$ & $\mathrm{Ca}$ & $\mathrm{P}$ & $\mathrm{Co}$ & $\mathrm{Cu}$ & $\mathrm{Zn}$ \\
\hline E1 & $\begin{array}{l}5 . \\
6\end{array}$ & 4.7 & $\begin{array}{c}50,5 \\
93\end{array}$ & 3,447 & 25,640 & $\begin{array}{c}20,5 \\
88\end{array}$ & 343 & $\begin{array}{l}2,6 \\
23\end{array}$ & 9,463 & 29,793 & 186 \\
\hline E2 & $\begin{array}{l}5 . \\
2\end{array}$ & 6.1 & $\begin{array}{c}39,0 \\
48\end{array}$ & 2,499 & 14,192 & $\begin{array}{c}57,9 \\
63\end{array}$ & 466 & 620 & 1,411 & 10,758 & 224 \\
\hline E3 & $\begin{array}{l}5 . \\
4\end{array}$ & 9.4 & $\begin{array}{c}31,8 \\
04\end{array}$ & 1,210 & 23,270 & $\begin{array}{c}8,15 \\
7\end{array}$ & 726 & 985 & 3,336 & 14,602 & 94 \\
\hline E4 & $\begin{array}{c}6 . \\
0\end{array}$ & 9.4 & $\begin{array}{c}61,1 \\
22\end{array}$ & 4,935 & 16,578 & $\begin{array}{c}16,0 \\
40\end{array}$ & $\begin{array}{l}1,0 \\
34\end{array}$ & 666 & 5,348 & 13,867 & 192 \\
\hline $\mathrm{Nm} 1$ & $\begin{array}{l}5 . \\
5\end{array}$ & 8.8 & $\begin{array}{c}82,3 \\
09\end{array}$ & 4,267 & 8,487 & $\begin{array}{c}18,0 \\
21\end{array}$ & $\begin{array}{l}1,1 \\
51\end{array}$ & 432 & 198 & 3,123 & 197 \\
\hline $\mathrm{Nm} 2$ & $\begin{array}{l}6 . \\
2\end{array}$ & 4.4 & $\begin{array}{c}45,6 \\
99\end{array}$ & 10,480 & 2,693 & $\begin{array}{c}31,4 \\
11\end{array}$ & 379 & $\begin{array}{c}3,6 \\
12\end{array}$ & 214 & 49,760 & 171 \\
\hline $\mathrm{Nm} 3$ & $\begin{array}{c}5 . \\
1\end{array}$ & 12.8 & $\begin{array}{c}66,6 \\
57\end{array}$ & 2,309 & 8,559 & $\begin{array}{c}26,3 \\
16\end{array}$ & 678 & 534 & 132 & 9,723 & 551 \\
\hline $\mathrm{Nm} 4$ & $\begin{array}{l}4 . \\
9\end{array}$ & 5.1 & $\begin{array}{c}41,0 \\
50\end{array}$ & 1,856 & 6,848 & $\begin{array}{c}46,7 \\
89\end{array}$ & 313 & 265 & 140 & 3,680 & 75 \\
\hline VK1 & $\begin{array}{l}5 . \\
0\end{array}$ & 7.0 & $\begin{array}{c}17,8 \\
36\end{array}$ & 118 & 8,463 & $\begin{array}{c}2,86 \\
6\end{array}$ & 424 & 444 & 53 & 1,793 & 224 \\
\hline VK2 & $\begin{array}{l}5 . \\
2\end{array}$ & 6.8 & $\begin{array}{c}14,4 \\
03\end{array}$ & & & $\begin{array}{c}1,86 \\
8\end{array}$ & 491 & 438 & 115 & 7,343 & 472 \\
\hline VK3 & $\begin{array}{l}5 . \\
0\end{array}$ & 4.7 & $\begin{array}{c}14,6 \\
44\end{array}$ & & 6,710 & $\begin{array}{c}2,29 \\
7\end{array}$ & 587 & 146 & 31 & 576 & 157 \\
\hline VK4 & $\begin{array}{l}5 . \\
0\end{array}$ & 13.5 & $\begin{array}{c}22,8 \\
28\end{array}$ & 66 & 3,879 & $\begin{array}{c}1,98 \\
3\end{array}$ & 705 & 466 & 131 & 8,957 & 622 \\
\hline Ru1 & $\begin{array}{l}5 . \\
0\end{array}$ & 10.3 & $\begin{array}{c}51,7 \\
81\end{array}$ & 772 & 6,989 & $\begin{array}{c}48,1 \\
98\end{array}$ & 376 & 417 & 145 & 2,658 & 162 \\
\hline Ru2 & $\begin{array}{l}5 . \\
3\end{array}$ & & $\begin{array}{c}48,0 \\
43\end{array}$ & 376 & 4,944 & $\begin{array}{c}7,16 \\
0\end{array}$ & 437 & 418 & 335 & 1,147 & 85 \\
\hline Ru3 & $\begin{array}{l}5 . \\
1\end{array}$ & 3.8 & $\begin{array}{c}64,4 \\
25\end{array}$ & 550 & 4,323 & $\begin{array}{c}4,97 \\
5\end{array}$ & 481 & 391 & 309 & 1,767 & 160 \\
\hline
\end{tabular}


Table 3.

Assuming $\mathrm{Ca}$ and $\mathrm{Mg}$ bind to $\mathrm{HM}$

Sample $\quad \mathrm{Co}-\mathrm{HM} \quad \mathrm{Co}-\mathrm{FeOx}$ Co-MnOx Co-inorg $\mathrm{Cu}-\mathrm{HM} \quad \mathrm{Cu}-\mathrm{FeOx} \quad \mathrm{Cu}-\mathrm{MnOx} \mathrm{Cu}-\mathrm{inorg} \quad \mathrm{Zn}-\mathrm{HM} \quad \mathrm{Zn}-\mathrm{FeOx} \mathrm{Zn}-\mathrm{MnOx} \mathrm{Zn}-\mathrm{inorg}$

\begin{tabular}{|c|c|c|c|c|c|c|c|c|c|c|c|c|}
\hline E1 & 3 & 3 & 10 & 84 & 11 & 79 & 0 & 10 & 8 & 7 & 1 & 85 \\
\hline E2 & 2 & 3 & 39 & 56 & 24 & 67 & 2 & 7 & 13 & 7 & 4 & 75 \\
\hline E3 & 10 & 5 & 10 & 75 & 32 & 63 & 0 & 5 & 29 & 8 & 1 & 62 \\
\hline E4 & 5 & 49 & 28 & 18 & 17 & 83 & 0 & 0 & 21 & 65 & 2 & 12 \\
\hline $\mathrm{Nm} 1$ & 0 & 4 & 94 & 2 & 38 & 59 & 3 & 0 & 19 & 37 & 36 & 8 \\
\hline $\mathrm{Nm} 2$ & 1 & 0 & 32 & 67 & 9 & 47 & 7 & 38 & 3 & 1 & 3 & 93 \\
\hline $\mathrm{Nm} 3$ & 2 & 2 & 81 & 15 & 39 & 54 & 4 & 2 & 30 & 11 & 18 & 41 \\
\hline $\mathrm{Nm} 4$ & 1 & 1 & 78 & 20 & 36 & 50 & 8 & 6 & 13 & 6 & 19 & 62 \\
\hline VK1 & 29 & 3 & 21 & 48 & 84 & 14 & & 1 & 69 & 3 & 1 & 27 \\
\hline VK2 & 9 & 1 & 2 & 88 & 57 & 26 & 0 & 18 & 24 & 1 & 0 & 75 \\
\hline VK3 & 34 & 6 & 11 & 49 & 91 & 9 & 0 & 0 & 76 & 5 & 0 & 19 \\
\hline VK4 & 28 & 1 & 2 & 69 & 76 & 18 & 0 & 6 & 53 & 1 & 0 & 46 \\
\hline $\mathrm{Ru} 1$ & 3 & 6 & 65 & 26 & 59 & 40 & 1 & 1 & 33 & 18 & 8 & 41 \\
\hline $\mathrm{Ru} 2$ & 28 & 26 & 18 & 29 & 87 & 13 & 0 & 0 & 75 & 16 & 0 & 9 \\
\hline Ru3 & 11 & 14 & 28 & 47 & 41 & 58 & 0 & 1 & 41 & 22 & 2 & 36 \\
\hline
\end{tabular}

Assuming $\mathrm{Ca}$ and $\mathrm{Mg}$ do not bind to $\mathrm{HM}$

Sample Co-HM Co-FeOx Co-MnOx Co-inorg $\quad \mathrm{Cu}-\mathrm{HM} \quad \mathrm{Cu}-\mathrm{FeOx}$ Cu-MnOx Cu-inorg Zn-HM Zn-FeOx Zn-MnOx Zn-inorg

$\begin{array}{llllllllllll}\text { E2 } & 8 & 1 & 21 & 70 & 38 & 50 & 1 & 11 & 26 & 2 & 2\end{array}$

$\begin{array}{lllllllllllllll}\text { E3 } & 12 & 1 & 6 & 82 & 44 & 45 & 0 & 11 & 29 & 2 & 0 & 69\end{array}$

$\begin{array}{lllllllllllll}\text { E4 } & 39 & 11 & 16 & 34 & 30 & 70 & 0 & 0 & 68 & 12 & 1 & 19\end{array}$

$\begin{array}{llllllllllllll}\mathrm{Nm} 1 & 57 & 0 & 43 & 0 & 87 & 3 & 10 & 0 & 93 & 0 & 7 & 0\end{array}$

$\begin{array}{lllllllllllll}\mathrm{Nm} 2 & 1 & 0 & 24 & 75 & 9 & 47 & 6 & 38 & 3 & 1 & 2 & 94\end{array}$

$\begin{array}{llllllllllllllll}\mathrm{Nm} 3 & 49 & 0 & 47 & 3 & 71 & 25 & 3 & 1 & 90 & 1 & 4 & 4\end{array}$

$\begin{array}{llllllllllllllll}\mathrm{Nm} 4 & 38 & 0 & 57 & 5 & 71 & 22 & 6 & 1 & 84 & 1 & 7 & 8\end{array}$

$\begin{array}{lllllllllllll}\text { VK1 } & 97 & 0 & 3 & 0 & 99 & 0 & 0 & 0 & 100 & 0 & 0 & 0\end{array}$

$\begin{array}{lllllllllllllll}\text { VK2 } & 12 & 0 & 2 & 86 & 61 & 23 & 0 & 16 & 30 & 1 & 0 & 70\end{array}$

$\begin{array}{lllllllllllll}\text { VK3 } & 100 & 0 & 0 & 0 & 100 & 0 & 0 & 0 & 100 & 0 & 0 & 0\end{array}$

$\begin{array}{lllllllllllll}\text { VK4 } & 70 & 0 & 2 & 28 & 85 & 13 & 0 & 2 & 82 & 1 & 0 & 17\end{array}$

$\begin{array}{llllllllllllll}\text { Ru1 } & 92 & 0 & 8 & 0 & 98 & 1 & 2 & 0 & 99 & 0 & 1 & 0\end{array}$

$\begin{array}{lllllllllllll}\mathrm{Ru} 2 & 99 & 0 & 1 & 0 & 99 & 0 & 1 & 0 & 100 & 0 & 0 & 0\end{array}$

$\begin{array}{lllllllllllll}\mathrm{Ru} 3 & 78 & 1 & 20 & 1 & 74 & 25 & 1 & 0 & 96 & 1 & 1 & 1\end{array}$


Table 4

\begin{tabular}{|c|c|c|c|c|c|c|c|c|c|c|}
\hline & \multicolumn{2}{|c|}{ Co total } & \multicolumn{2}{|c|}{$\begin{array}{l}\text { Co-HM } \\
\text { mea }\end{array}$} & \multicolumn{2}{|c|}{$\mathrm{Co}-\mathrm{FeO} \mathrm{x}$} & \multicolumn{2}{|c|}{$\begin{array}{l}\mathrm{Co}-\mathrm{MnOx} \\
\text { mea }\end{array}$} & \multicolumn{2}{|c|}{$\begin{array}{l}\text { Co-inorg } \\
\text { mea }\end{array}$} \\
\hline & mean & $\mathrm{sd}$ & $\mathrm{n}$ & $\mathrm{sd}$ & mean & $\mathrm{sd}$ & $\mathrm{n}$ & $\mathrm{sd}$ & $\mathrm{n}$ & $\mathrm{sd}$ \\
\hline & 4,889 & & $228^{\mathrm{a}}$ & & & & & & 3,05 & 3,35 \\
\hline E & & 3,447 & $\mathrm{~b}$ & 136 & $778^{a}$ & 1232 & $832^{\mathrm{a}}$ & 511 & $1^{\mathrm{a}}$ & 5 \\
\hline $\mathrm{Nm}$ & $171^{\mathrm{c}}$ & 41 & $2^{\mathrm{b}}$ & 1 & $3^{b}$ & 3 & $118^{\mathrm{c}}$ & 49 & $49^{b}$ & 64 \\
\hline VK & $82^{\mathrm{b}}$ & 48 & $18^{\mathrm{a}}$ & 12 & $1^{b}$ & & $5^{b}$ & 4 & $58^{\mathrm{b}}$ & 44 \\
\hline & $208^{\mathrm{ab}}$ & & & & & & & & & \\
\hline \multirow{5}{*}{$\begin{array}{l}\mathrm{Ru} \\
\text { Kruskall Wallis } \\
\text { test }(\mathrm{H})\end{array}$} & & 139 & $33^{\mathrm{ab}}$ & 43 & $36^{\mathrm{ab}}$ & & $73^{a b c}$ & 21 & $86^{\mathrm{ab}}$ & 46 \\
\hline & $12.6^{*}$ & & 10.7 & & & & & & & \\
\hline & \multirow{2}{*}{\multicolumn{2}{|c|}{$\mathrm{Cu}$ total }} & \multirow{2}{*}{\multicolumn{2}{|c|}{$\begin{array}{l}\mathrm{Cu}-\mathrm{HM} \\
\text { mea }\end{array}$}} & \multirow{2}{*}{\multicolumn{2}{|c|}{$\mathrm{Cu}-\mathrm{FeO} \mathrm{x}$}} & \multirow{2}{*}{\multicolumn{2}{|c|}{$\begin{array}{l}\mathrm{Cu}-\mathrm{MnOx} \\
\text { mea }\end{array}$}} & \multirow{2}{*}{\multicolumn{2}{|c|}{$\begin{array}{l}\text { Cu-inorg } \\
\text { mea }\end{array}$}} \\
\hline & & & & & & & & & & \\
\hline & mean & sd & $\mathrm{n}$ & $\mathrm{sd}$ & mean & sd & $\mathrm{n}$ & sd & $\mathrm{n}$ & $\mathrm{sd}$ \\
\hline \multirow{3}{*}{$\mathrm{E}$} & 17,25 & & 3,22 & 1,04 & 12,86 & 7.329 & $54^{\mathrm{abc}}$ & 108 & 1,11 & 1,29 \\
\hline & 5 & & 2 & 3 & & & & & 6 & \\
\hline & 16,57 & 22,32 & 2,69 & 1,68 & 8,080 & 10,33 & 1,06 & 1,61 & 4,83 & 9,38 \\
\hline $\mathrm{Nm}$ & 2 & 7 & 6 & 7 & $a b$ & 0 & $5^{b}$ & 7 & 1 & 6 \\
\hline VK & 4,667 & 4,105 & $\begin{array}{r}3,25 \\
6\end{array}$ & $\begin{array}{r}2,82 \\
8\end{array}$ & $956^{\mathrm{b}}$ & 941 & $0^{\mathrm{a}}$ & 0 & 469 & 621 \\
\hline & 6075 & 10,25 & 1,24 & 450 & 3,142 & 4811 & $411^{\mathrm{ac}}$ & 804 & 2,35 & 4,68 \\
\hline $\mathrm{Ru}$ & 0,915 & & & 459 & & 4,811 & & 804 & 8 & \\
\hline $\begin{array}{l}\text { Kruskall Wallis } \\
\text { test }(\mathrm{H})\end{array}$ & & & NS & & $10.1^{*}$ & & $7.9^{*}$ & & NS & \\
\hline
\end{tabular}




\section{Highlights}

- Cobalt and copper fractionation in soils was investigated in order to understand their mobility in soil.

- Cobalt and copper fractionation was modeled using Windermere Humic Aqueous Model (WHAM 6).

- Positive correlation between organic-bound and inorganic Co concentratio and concentrations of extractable Co was found.

- Speciation modeling shows a strong affinity of Mn-oxides for Co, which can explain the lower Co availability of Mn-rich soils.

- High $\mathrm{Mn}$ and Fe status of $\mathrm{Cu}-\mathrm{Co}$ soil in Katanga may actually exert a protective effect against the toxic effects of Co. 